\title{
Role of big data analytics in developing sustainable capabilities
}

\author{
Sanjay Kumar Singh ${ }^{\text {a, }}{ }^{*}$, Abdul-Nasser El-Kassar ${ }^{\text {b }}$ \\ a College of Business, Abu Dhabi University, Abu Dhabi, United Arab Emirates \\ ${ }^{\mathrm{b}}$ Adnan Kassar School of Business, Lebanese American University, Beirut, Lebanon
}

\section{A R T I C L E I N F O}

\section{Article history:}

Received 15 September 2018

Received in revised form

9 December 2018

Accepted 18 December 2018

Available online 27 December 2018

\section{Keywords:}

Sustainable capabilities

Big data

Corporate commitment

Green supply chain management

Green human resource management practices

And environmental \& organizational performance

\begin{abstract}
A B S T R A C T
The purpose of this study is to examine the extent of sustainable capabilities driven by corporate commitment resulting from the integration of big data technologies, green supply chain management, and green human resource management practices, and the extent to which these capabilities can enhance the broader firm performance. The study was also designed to investigate the degree to which green human resource management practices influence the integration of big data technologies with processes and enhance the relationships between green supply chain management practices, both internal and external, as well as their influence on sustainable performance. We used dynamic capabilities theory and proposed a conceptual research model which was tested empirically. The findings of our study establish the influence of big data driven strategies on business growth in terms of sustainable performance by considering internal processes that constitute sustainable capabilities. The study recommends the integration of green supply chain management, green human resource management practices, and big data management to enhance firms' sustainable capabilities that lead to better sustainable performance.
\end{abstract}

() 2019 Elsevier Ltd. All rights reserved.

\section{Introduction}

Big data has the potential to transform business and that warrants understanding the implications, vis-à-vis organizational responses, to the opportunities and challenges of environmentally sustainable business operations (Seles et al., 2018) and supply chain sustainability (Papadopoulos et al., 2017a,b). However, the traditional means of acquiring, accessing and analyzing big data are no longer applicable (Seles et al., 2018; Tien, 2013; Hampton et al., 2013). Decision makers use big data analytics to devise strategies that translate into better firm performance through innovation, competitiveness and values creation (de Camargo Fiorini et al., 2018; Fosso-Wamba et al., 2017; Tan et al., 2015). However, the internal mechanisms, namely capabilities, core competencies, and internal processes through which the formulated strategies from big data analytics lead to higher performance, have not yet been fully examined. As a result, we contend that building the required organizational capabilities requires not only big data management, data science and predictive analytics but other factors and mechanisms, namely supply chain management (SCM) and human

\footnotetext{
* Corresponding author.

E-mail address: sanjay.singh@adu.ac.ae (S.K. Singh).
}

resource management (HRM) (e.g., Jabbour and de Sousa Jabbour, 2016; Jabbour et al., 2013; Jackson et al., 2011). Bundling these technologies along with HRM and SCM helps firms achieve future sustainability and create core competency (Amui et al., 2017; Dao et al., 2011).

Environmental sustainability and greening of organizations have become the agenda of the 21st century; and as a result, "Green Human Resource Management" (GHRM) in the field of human resources (Jabbour and de Sousa Jabbour, 2016; Jabbour et al., 2013; Jackson et al., 2011) and sustainability in the field of operations management (Jabbour and de Sousa Jabbour, 2016; Govindan et al., 2014) have emerged as new lines of research. For the purpose of this study, we define GHRM as alignment of HRM practices with environmental management practices wherein human resources play a strategic role while deciding upon organization's environmental policies and practices (e.g., Jackson and Seo, 2010; Jabbour and Santos, 2008). Similarly, we define sustainability as the ability of firms to respond to not only their short-term financial objectives bust also their future goals (Bansal and DesJardine, 2014). Managing sustainable resources and reducing pollution pose several challenges to firms' economic development over the years that calls upon the firms' top management to find ways to reduce and manage them in sustainable ways (Song et al., 2017; Wang and Song, 2014). We argue that if the firms do not take care of 
environmental sustainability on their own, key stakeholders will be forced to implement environment-friendly practices and ecoefficient activities (Carvalho et al., 2017; Chen and Chang, 2012; Chen and Delmas, 2012). Therefore, we posit that organizations should implement environment-friendly practices such as the implementation of green supply chain management, green technologies and green innovation for a win-win situation. Green innovations support sustainable development as well as technological innovations that are used in waste recycling, saving energy and preventing pollution, if any (Gast et al., 2017; Chang, 2011).

The capacity to integrate intricate resources in an effective manner to achieve sustainable goals, deliver sustained values to its stakeholders, and gain sustainable competitive advantage constitute a firm's sustainable capabilities (Amui et al., 2017; Dao et al., 2011). Hence, by integrating green HRM, green supply SCM and big data management, firms develop such sustainable capabilities that lead to better sustainable performance, not only at the organizational, but also at the environmental and social levels (Amui et al., 2017; Dao et al., 2011). Previous studies on sustainability and sustainable capabilities of firms ask for serious scholarly attention using a wide array of methodological choices ranging from conceptual and theoretical works to mixed methodologies, including quantitative and qualitative (e.g., Amui et al., 2017; Papadopoulos et al., 2017a,b), as there is a scarcity of scholarly works on this theme. Furthermore, the exiting literature on sustainability identifies a considerable gap in investigating the obstacles to becoming a sustainable firm with green SCM, green HRM, corporate commitment, and how dynamic capability theory can contribute to this qualitatively (e.g., Amui et al., 2017; Govindan et al., 2015; Gmelin and Seuring, 2014) for firms to attain sustainable performance.

We posit that integrating the firm's resources to develop sustainable capabilities to achieve sustainable performance relies on corporate commitment to engage in sustainable practices and big data initiatives that are incorporated at the firm's operational and strategic levels. This requires decision makers to adopt a comprehensive and viable process that ensures returns from investments made in big data initiatives (Acharya et al., 2018; Braganza et al., 2017). Such practice involves three stages consisting of big data acceptance, assimilation and routinization (Wang et al., 2018; Gunasekaran et al., 2017; Hazen et al., 2012). Driven by commitment from decision makers, the acceptance stage is about how stakeholders recognize the significance of such technologies (Gunasekaran et al., 2017). The routinization stage is related to a firm's governance system that enables the incorporation of the technologies within the processes (Wang et al., 2018; Gunasekaran et al., 2017; Zmud and Apple, 1992). The assimilation stage refers to how well technology has been integrated or spread across the firm's processes so that expected goals and benefits are attained (Wang et al., 2018; Gunasekaran et al., 2017; Hazen et al., 2012).

Our study extends the prior studies on environmental sustainability and greening of organizational processes and practices (Jabbour and de Sousa Jabbour, 2016; Jabbour et al., 2013; Jackson et al., 2011). This paper also extends prior scholarly studies on the linkages amongst big data technologies, green HRM, green SCM and firms' operational and environmental performance (e.g., El-Kassar and Singh, 2018; Amui et al., 2017; Govindan et al., 2015). In particular, our study attempts to address following questions:

- How do sustainable capabilities driven by corporate commitment and resulting from the integration of big data technologies, green HRM practices and green SCM enhance firms' operational and environmental performance?
- How do green HRM practices influence the integration of big data technologies within organizational processes to augment the relationships between internal and external green SCM practices and, in turn, how do they influence sustainable performance?

We have organized our paper as follows: The underlying theoretical framework used to develop the proposed conceptual model is presented in section two along with a review of the related literature required to derive the hypotheses. In section three, we present the research methodology and data analysis. The discussions and conclusions along with the limitations and suggestions for future research are presented in section four.

\section{Theory and hypotheses}

We draw upon the dynamic capabilities (DC) theoretical lens that aims at addressing changes through integrating and reconfiguring competencies internally and externally (Teece et al., 1997). Effective reconfiguration and transformation of organizational competencies leads to their renewal and requires the firm's awareness of environmental changes as well as constant observation and adoption of new technologies and best practices. However, the development of such dynamic capabilities is limited by organizational characteristics and managers' choices. Argote (2012) argues that managers who rely on existent knowledge and past experiences face organizational challenges especially when operating in a non-linear market. This urges firms to innovate and leaders to reorganize their knowledge by using real-time information, cross-functional relationships, and other communication options. Zollo and Winter (2002) distinguish between implicit and explicit knowledge and posit that dynamic capabilities develop in accordance with direct knowledge declaration and codification activities.

The dynamic capabilities view attempts to reveal characteristics of the firm's capabilities in terms of creating resource combinations that relate common business processes, such as product development, resources allocation and knowledge creation processes (Eisenhardt and Martin, 2000). Moreover, increased reliance on such capabilities helps the firm achieve a competitive advantage by enabling new thinking techniques and combining data, technologies and expertise. In the context of sustainability and greening of firms, we posit that sustainable dynamic capabilities refer to the ways in which firms configure and continually reconfigure big data technologies, green HRM practices, green SCM, and corporate commitment to achieve sustainable operational and environmental performances (e.g., Eisenhardt and Martin, 2000; Teece et al., 1997). Furthermore, dynamic capabilities suggest how firms engage in exploiting their big data, reconfiguring resources to make big data initiatives repeatable and sustainable rather than an isolated event (Braganza et al., 2017). Several studies relating to big data analytics exhibit the applicability of the dynamic capabilities view, wherein they argue that big data technologies are resources that support firms operating in rapidly changing environments and market conditions due to features explicitly associated with dynamic capabilities (e.g., Braganza et al., 2017; Fosso-Wamba et al., 2017; Kindström et al., 2013).

Gunasekaran et al. (2017) examined the influence of assimilation on both supply chain and firm performance. Driven by top management commitment, the acceptance stage concerns how stakeholders appreciate the significance of such technologies (Gunasekaran et al., 2017). The routinization stage deals with the governance system of the firm that enables the integration of the technologies within processes (Zmud and Apple, 1992). The assimilation stage is related to the extent that firms integrate or 
spread over their processes and practices so that expected goals and benefits are attained (Hazen et al., 2012). Big data analytics use unique information processing capabilities in the organizational value creation processes to enhance a firm's competitive advantage and the support and commitment of top management play a critical role in that direction (e.g., El-Kassar and Singh, 2018; Chen et al., 2015). Accordingly, we predict that:

H1. Corporate commitment has a positive impact on acceptance, routinization and assimilation of big data.

Large data assimilation through acceptance and routinization along with resources, namely connectivity and information sharing driven by corporate commitment (capability), impact the supply chain practices and enhance firm performance (Gunasekaran et al., 2017). Aiming at addressing the rapid technological changes through the integration of these capabilities requires the firm's awareness of environmental changes and commitment from decision makers to address challenges presented by these changes. Faced with natural resource depletion and dynamic market changes, firms are now obliged to utilize and manage resources in a sustainable manner. This poses several challenges on firms' economic development (Wang and Song, 2014) and forces them to implement environment-friendly practices and engage in ecoefficient activities that have a high economic value and social consideration while still delivering sustainable values (Carvalho et al., 2017; Chen and Chang, 2012; Chen and Delmas, 2012).

Environment-friendly practices, such as the implementation of internal and external green SCM, green technologies, and green innovation, should not only be considered, but also encouraged by the decision makers through corporate commitment. Green innovations is a crucial strategic factor that supports sustainable development through continuous usage of technological innovation while saving energy, recycling of wastes and prevention of pollution (Chang, 2011). Therefore, effective implementation of green innovation practices (i.e., internal supply chain management) must be accompanied with the collaboration of all supply chain partners (Chithambaranathan et al., 2015). In particular, the supply chain system becomes green when the suppliers embrace environmental requirements of both firms and customers. Chiou et al. (2011) show that when suppliers adopt environment-friendly practices, it increases green product innovations that, in turn, enhance firms' competitive advantage and environmental performance. Moreover, green supply chain management (GSCM) emerged as an environmental strategy that not only improves the environmental performance of individual organizations, but also that of the entire supply chain which has also been accepted by industries (Govindan et al., 2016). Hence, we propose that:

H2. Corporate commitment positively influences internal and external green SCM practices.

Chen and Zhang (2014) posit that although excessive amounts of data generated and collected by firms are becoming more challenging for decision makers, they are profoundly useful due to their potential and hidden values. Big data offers huge opportunities pertinent to businesses operating in different fields and industrial sectors and that can result in increased productivity and enhanced financial performance (Nguyen et al., 2017). This marks large voluminous data as a valuable asset or exploration that will be involved in future business competition in technology and productivity. Many challenges are also associated with big data, including problems with data capture, storage, analysis, and visualization. Also, several useful techniques may be adopted to deal with big data problems, such as cloud computing (Hashem et al., 2015). These technologies and techniques aim for the advancement and development of complex methods for managing and analyzing information located in diverse, numerous and heterogeneous data sets. Waller and Fawcett (2013) examined areas where SCM converges with predictive analytics and data science, as well as large data. In particular, the importance of the skills and knowledge required for future supply chain leaders to be effective were pointed out.

Nguyen et al. (2017) proposed a framework that provides a comprehensive view of the usage of big data analytics in the SCM context, which is one of the few key business aspects affected by large data analytics due to the implementation of data-driven strategies and operations. Such transformation allows firms to attain operational excellence and competitive advantage. In fact, end-to-end supply chains manage their widespread activities by linking data sets located in different systems across the supply chain. Data-driven strategies applied in supply chains include RFID tags which screen the compliance of available inventory levels and that in-transit with current stock levels. This in turn automates inventory order replacement. Moreover, big data increases a firm's value when it is incorporated with other key organizational resources (Sanders, 2014) to impact firms' SCM practices (Mishra et al., 2018). Therefore, we predict that:

H3. The assimilation of big data through acceptance and routinization has a positive impact on internal green SCM practices.

The inflow of large data in huge quantity, high diversity, and high velocity is associated with challenges for classical environmental theories and methods notwithstanding them being defective in exactness and constancy (Acharya et al., 2018; El-Kassar and Singh, 2018; Song et al., 2017). Big data has characteristic features that possess environmental and social features to impact the innovation and performance (Cajaiba-Santana, 2014; El-Kassar and Singh, 2018; Roßmann et al., 2018; Papadopoulos et al., 2017a,b) of the supply chain. Dubey et al. (2017), in a study in Indian manufacturing organizations, found that big data and predictive analytics positively impact firms' social and environmental performance. Several other scholars also studied how big data analytics help firms to reduce negative influence of carbon emission (e.g., Zhao et al., 2017; An et al., 2017) and also improve firms' social sustainability (Song et al., 2017), economic performance (Akter et al., 2016) and social, environmental and economic performance (Jeble et al., 2018). Furthermore, Seles et al. (2018) have analyzed the challenges and opportunities of climate change for business organizations and suggest that big data analytics has potential to transform ways of doing business while staying focused on sustainable operational and environmental performance. Therefore, we predict that:

H4. The assimilation of big data through acceptance and routinization has a positive influence on environmental and organizational performance.

Green innovations help firms to attain sustainable development through technological innovation to save energy, recycle the wastes and prevent pollution, if any (Chang, 2011). Chen et al. (2006) suggest that green innovations include green products and processes that help reduce energy and pollution emission, waste recycling, and deployment of sustainable resources. Several past studies pinpoint, among others, corporate commitment and environmental ethics that contribute to the success of implementing green innovation in the workplace (Weng et al., 2015; Lin et al., 2013; Chang, 2011). Firms have been found to design and implement green SCM practices to reduce the environmental impact of their operations and that, in turn, enhances their operational performance (Vanalle et al., 2017). Similarly, a study by Longoni and 
Cagliano (2018) found a combined effect of a firm's inclusive environmental disclosure and green SCM practices on its environmental and financial performance. In other words, firms should align and leverage green SCM for disclosure practice effectiveness and, in turn, to augment their environmental and financial performance (Longoni and Cagliano, 2018). Therefore, we posit that green SCM practices, namely cooperation with customers and green purchasing on the firm's environmental performance (de Sousa Jabbour et al., 2017) and how green collaboration with suppliers and green process innovation, facilitate firms remaining competitive (Dai et al., 2017) in dynamic markets. As a result, we hypothesize that:

H5. Internal and external green SCM practices positively influence environmental and organizational performance.

Technological challenges in assimilating big data become huge when firms embrace green SCM and sustainable practices internally as well as externally with their supply chain partners. Such challenges are handled through corporate commitment and green HR practices which aim at improvement in environmental and organizational performance (Rajesh, 2017; Gunasekaran et al., 2017; Ar, 2012). Yen and Yen (2012) studied how internal motivations influence organizations to embrace green SCM and found a direct association between corporate commitment and successful adoption of green standards. Gholami et al. (2013) further discussed conditions and results where firms embraced green technologies and found a positive relationship between 'going green' policies and practices and their environmental performance. Therefore, green HR practices facilitate adoption of green management, green technologies and green operations management. We posit that green HR practices contribute to organizational sustainability and boost firm performance (El-Kassar and Singh, 2018; Jabbour and de Sousa Jabbour, 2016; Boudreau et al., 2003). Accordingly, we posit the following hypothesis:

H6. Green HR practices and training influence big data acceptance on routinization, green supply chain collaboration on internal green SCM, and internal green SCM on environmental and organizational performance.
The above discussions and hypotheses are depicted in our conceptual model of Fig. 1.

\section{Methods}

\subsection{Survey and data collection}

Our study is designed to find out the influence of the large data driven strategies on sustainable performance by considering internal processes that constitute sustainable capabilities. In this study, we also examine the relationships between the assimilation of big data, internal and external green SCM practices, and sustainable performance (organizational and environmental), along with the influence of decision makers' commitment. Our study also examines the moderating effects of green HR management, in terms of green HR training and practices, on the aforementioned relationships.

Using a survey instrument designed to measure the construct and test the hypotheses, we examined the conceptual model of our study. First, an initial questionnaire was designed and the scale was checked via content validity. With the help of six academic professors and three industry experts, the survey was further developed. The revised version was used to test our proposed research model. The survey items aimed at measuring the respondents' attitudes and opinions regarding the various constructs. A discussion of the items measuring these constructs is given below.

The target population consisted of employees and managers working in organizations that had implemented big data and adopted green SCM practices. Respondents were knowledgeable about big data technologies, SCM practices and the broader performance of their organizations. We used convenient sampling and approached the potential sample of the study through personal networks. A total of 522 potential respondents were asked via email to participate in the study. The model was tested and the research questions were addressed using data collected from 257 employees. The sample in the study were employees working in companies located in the Kingdom of Saudi Arabia (KSA), the United Arab Emirates (UAE), Egypt, and Lebanon. Egypt and Lebanon are two Middle East and North Africa (MENA) countries,

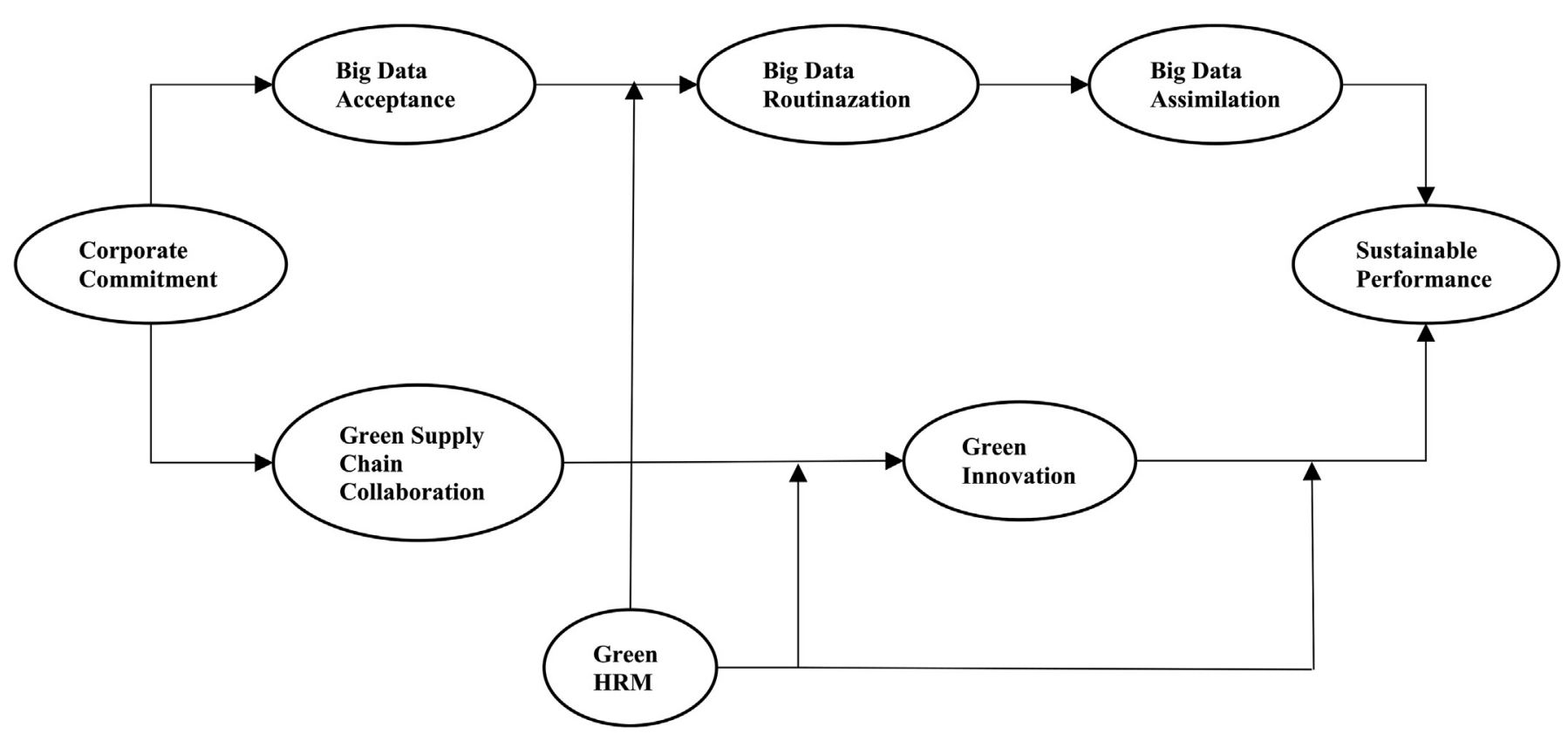

Fig. 1. The conceptual research model. 
while the KSA and the UAE are two Golf-Cooperation Countries (GCC). We attached a cover letter to the questionnaire explaining the purpose of the study. Moreover, in the cover letter assurance of the anonymity of the respondents and answers was stressed. This was aimed to minimize social desirability biases that particularly arise in survey research, especially in small firms (Roxas and Lindsay, 2012). This study had 215 usable returned questionnaires from the respondents, yielding a 53.80 percent response rate.

We contacted 23 non-respondents to check for non-response bias and asked them about the reasons for their non-participation in this study. It was found that the main reason for their nonparticipation was their lack of knowledge of the constructs of the study and the resulting items included in the survey questionnaire. In addition, we used the demographic values to perform Chi-Square test to compare between early respondents (those who returned the survey questionnaire in the first two weeks from the receipt of the questionnaire) and late respondents (who returned filled-in questionnaire after 20-25 days and after they were contacted several times). We found no significant differences in the early respondents and the late respondents. Therefore, it provided further confirmation that our study is free from any issue related to the non-response bias.

\subsection{Measures}

Multiple-scale items were used to the measure all the constructs of the conceptual model. In addition to the demographic items of the company, a total of fifty-one items were included to cover the constructs of the conceptual research model. These items are listed in Table 1.

Four items from Chiou et al.'s (2011) scale were used to measure green product innovations. The sample items of green product

Table 1

Construct items.

\begin{tabular}{|c|c|c|c|}
\hline Construct & & Construct items & References \\
\hline \multirow[t]{5}{*}{ Corporate Commitment (CCMT) } & CMT1 & Business benefits through green supply chain partnering & Liang et al. (2007) \\
\hline & CMT2 & Green supply chain partnering to stay competitive & \\
\hline & CMT3 & Articulating ideas to support green SCM partnership & \\
\hline & CMT4 & Monitoring success of green SCM partnership & \\
\hline & CMT5 & Formulating strategy for information sharing in the organization & \\
\hline \multirow[t]{3}{*}{ Big Data Acceptance (BDACP) } & ACP1 & BDPA enhances employees' job performance & Hazen et al. (2012) \\
\hline & ACP2 & Employees in organization associate with BDPA systems & \\
\hline & ACP3 & Presence of organizational \& technical infrastructure & \\
\hline \multirow[t]{5}{*}{ Big Data Routinization (BDRT) } & RTN1 & Firms allocate normal budgeting for BDPA & Hazen et al. (2012) \\
\hline & RTN2 & Firms to have existence of dedicated unit for BDPA & \\
\hline & RTN3 & Obtaining technical support as per organizational procedures & \\
\hline & RTN4 & Hiring and retaining able \& qualified employees & \\
\hline & RTN5 & To provide opportunities for BDPA training & \\
\hline \multirow[t]{4}{*}{ Big Data Assimilation (BDAS) } & ASM1 & BADS as vital instrument in each department & Hazen et al. (2012); Liang et al. \\
\hline & ASM 2 & BADS as vital instrument for decision making & $(2007)$ \\
\hline & ASM 3 & BADS as vital instrument for Operations & \\
\hline & ASM 4 & BADS as vital instrument for management & \\
\hline \multirow{5}{*}{$\begin{array}{l}\text { Green Supply Chain Collaboration } \\
\quad(\text { GSCC) }\end{array}$} & SCC1 & Supplier selection on environmental criteria & Chiou et al. (2011) \\
\hline & SCC2 & Seminars \& training on environmental awareness to the suppliers & \\
\hline & SCC3 & Advising suppliers on environmental technical issues & \\
\hline & SCC4 & Engaging suppliers in product design \& development & \\
\hline & SCC5 & Appraising environmental performance of the suppliers & \\
\hline \multirow[t]{5}{*}{ Green Process Innovation (GPRCINV) } & PCI1 & Less consumption of natural resources during production & Chiou et al. (2011) \\
\hline & $\mathrm{PCI} 2$ & Recycling, reusing, and remanufacturing resources & \\
\hline & $\mathrm{PCI} 3$ & Focus on using renewable technology & \\
\hline & $\mathrm{PCI} 4$ & $\begin{array}{l}\text { Redesigning manufacturing \& logistics processes for environmental } \\
\text { effectiveness }\end{array}$ & \\
\hline & PCI5 & Redesigning products/services as per environmental criteria & \\
\hline \multirow[t]{4}{*}{ Green Product Innovation (GPRDINV) } & PRI1 & Use of environmentally friendly materials & Chiou et al. (2011) \\
\hline & PRI 2 & Using materials which are easy to recycle, reuse \& decompose & \\
\hline & PRI 3 & Focus on recovering end-of-life products \& reutilizing & \\
\hline & PRI 4 & Use of eco-labeling & \\
\hline \multirow[t]{5}{*}{ Green HR Training (GHRTR) } & GHRT1 & Training provided to employees & De Kok et al. (2006) \\
\hline & GHRT2 & Formal employee training programs & \\
\hline & GHRT3 & Existing employee training programs & \\
\hline & GHRT4 & Use of internal staffs for in-house employee training & \\
\hline & GHRT5 & Use of external staffs for in-house employee training & \\
\hline \multirow[t]{5}{*}{ Green HR Practices (GHRPR) } & GHRP1 & Overall HR practices & Astrachan and Kolenko (1994) \\
\hline & GHRP2 & Formal \& regular employee appraisal process & \\
\hline & GHRP3 & Compensation policies & \\
\hline & GHRP4 & Written employee manual & \\
\hline & GHRP5 & Written job descriptions & \\
\hline \multirow[t]{6}{*}{ Environmental Performance (EP) } & EP1 & Decrement in air emission & Lin et al. (2013) \\
\hline & $\mathrm{EP} 2$ & Decrement of hazardous wastes & \\
\hline & EP3 & Decrement in consumption of fuel & \\
\hline & EP4 & Partnering with green suppliers & \\
\hline & EP5 & environmental obedience & \\
\hline & EP6 & Usage of environmental responsive material & \\
\hline \multirow[t]{4}{*}{ Organizational Performance (OP) } & OP1 & Improving firm's market situation & Lin et al. (2013) \\
\hline & OP2 & Increment in firm's sales volume & \\
\hline & OP3 & Increment in the firm's profit rate & \\
\hline & OP4 & Improvement in the firm's reputation & \\
\hline
\end{tabular}


innovations relate to environmentally sustainable resources which are recyclable, non-toxic, decomposable and clean. We used four items from Chiou et al. (2011) to measure green process innovation. The sample items included here related to how the designing of production and manufacturing processes satisfy the environmental criteria. In particular, the sample items aimed at 'determining consumption of the resources (ie., the oil, the gasoline, etc.)', 'the enhancement of the environmental efficiency and utilization of renewable technology', etc. We also used five items from Chiou et al. (2011) to measure green supply chain collaboration. The sample items included 'supplier selection on environmental criteria', 'seminars and training on environmental awareness to the suppliers', etc.

Corporate commitment was measured using a scale based on Liang et al. (2007). Corporate commitment denotes decision makers' commitment to environmental partnering, information sharing, acceptance of green ideas, vision for future collaboration and establishment of metrics to monitor the success of the supply chain through partnering. We measured big data adoption and routinization with three and five items, respectively, adopted from Hazen et al. (2012). On the other hand, the big data assimilation was measured using four items from Hazen et al. (2012) and Liang et al. (2007). We adopted five items from Astrachan and Kolenko (1994) to measure green HR practices (GHRP) while five items from De Kok et al. (2006) were used to measure green HR training (HRT). Furthermore, the environmental performance and the organizational performance scales had six and four items, respectively (Lin et al., 2013).

\subsection{Data analysis}

We used partial least squares structural equation modelling (PLS-SEM) using Smart PLS 3 to examine the hypotheses of our study. As compared to PLS-SEM, the traditional covariance-based SEM necessitates large sample size (Kline, 2012). PLS-SEM is a favorable approach to estimate a complex hierarchical model demonstrating the soft modelling assumptions; and several past studies in the domain of big data and business analytics also favored using PLS-SEM to test the complex models (e.g., El-Kassar and Singh, 2018; Papadopoulos et al., 2017a,b; Fosso Wamba et al., 2015).

The PLS-SEM method consist of two phases, namely the outer model validation and inner model path coefficients estimation. Wetzels et al. (2009) suggest validating the outer model to estimate reliability coefficients of the constructs along with their convergent and discriminant validity. Once validating the outer model, we fitted in the inner model to estimate the path coefficients. Thereafter, the bootstrap method was used to determine the significance of the results. We also used multi-group analysis to study the moderating influence of green HRM practices and training. This was accomplished through cluster analysis, a method employed to partition the respondents' firms according to their HR practices. This technique groups these firms into clusters in line with Kamakura and Wedel (2000) and De Sarbo et al. (1992). We used the cluster analysis technique for the group observations according to the characteristics of the latent variables. Thereafter, as per previous studies, the multi-group analysis was performed to find significant differences, if any, in the path coefficients across different groups (e.g., El-Kassar and Singh, 2018).

\subsection{Outer model analysis}

For all the latent variables, we used a reflective scheme wherein the unstandardized full dataset was used to analyze the model. The PLS-SEM method through SmartPLS3 software was used to calculate the convergent and the discriminant validity of the latent constructs. As in Fig. 2, the factor loadings of individual items of each of the construct were above 0.70 , which signifies that all constructs in this study had convergent validity. Hence, the underlying constructs explain the significant variance in all the observed variables (e.g., Hulland, 1999). Moreover, the bootstrapping method indicated that all the loadings were significant at 0.01 level of significance.

The average variance extracted (AVE) values of the constructs were $>0.5$ (see Table 2). Finally, we calculated Cronbach's alpha coefficients and scale composite reliability (listed in Table 2) which were above the cut-off point (e.g., Nunnally and Bernstein, 1994), which suggested that individual constructs in this study are

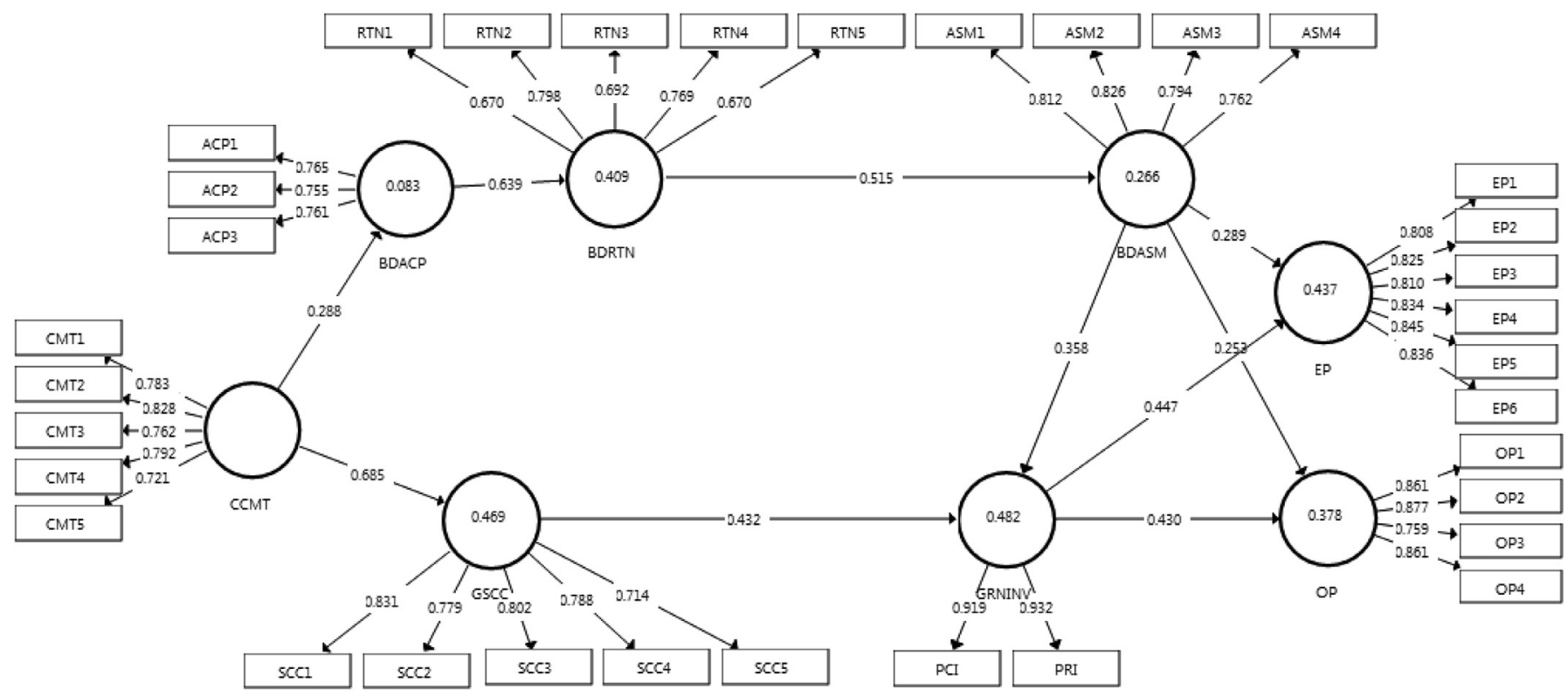

Fig. 2. PLS-SEM results of proposed model. 
Table 2

Construct reliability and validity.

\begin{tabular}{llll}
\hline & $\begin{array}{l}\text { Cronbach's } \\
\text { Alpha }\end{array}$ & $\begin{array}{l}\text { Composite } \\
\text { Reliability }\end{array}$ & $\begin{array}{l}\text { Average Variance } \\
\text { Extracted (AVE) }\end{array}$ \\
\hline BDACP & 0.636 & 0.805 & 0.579 \\
BDASM & 0.811 & 0.876 & 0.638 \\
BDRTN & 0.769 & 0.844 & 0.521 \\
CCMT & 0.837 & 0.885 & 0.606 \\
EP & 0.907 & 0.928 & 0.683 \\
GRNINV & 0.833 & 0.923 & 0.857 \\
GSCC & 0.843 & 0.888 & 0.614 \\
OP & 0.861 & 0.906 & 0.707 \\
\hline
\end{tabular}

unidimensional, have reflective properties, and possess high-scale reliability.

We also tested for discriminant validity and found all constructs to possess discriminant validity, as the AVE of any construct was greater than the shared variance of other constructs in this study (Fornell and Larcker, 1981). This is depicted in Table 3, which shows that the diagonal values are higher as compared to any of the values in their corresponding columns and rows.

\subsection{Inner model analysis}

First of all, we tested the model $\mathrm{R}^{2}$ values as a prerequisite to examine the inner model. The obtained outcomes suggest that the model explains satisfactory part of variance of the constructs and agreement with the recommended criterion (e.g., Chin, 1998); and the model has satisfactory nomological validity (Chin, 1998). Next,

Table 3

Discriminant validity.

\begin{tabular}{lllllllll}
\hline & BDACP & BDASM & BDRTN & CCMT & EP & GRNINV & GSCC & OP \\
\hline BDACP & $\mathbf{0 . 7 6 1}$ & & & & & & & \\
BDASM & 0.344 & $\mathbf{0 . 7 9 9}$ & & & & & & \\
BDRTN & 0.639 & 0.515 & $\mathbf{0 . 7 2 2}$ & & & & & \\
CCMT & 0.288 & 0.475 & 0.203 & $\mathbf{0 . 7 7 8}$ & & & & \\
EP & 0.221 & 0.554 & 0.330 & 0.605 & $\mathbf{0 . 8 2 7}$ & & & \\
GRNINV & 0.157 & 0.592 & 0.212 & 0.671 & 0.619 & $\mathbf{0 . 9 2 5}$ & & \\
GSCC & 0.289 & 0.542 & 0.323 & 0.685 & 0.650 & 0.626 & $\mathbf{0 . 7 8 4}$ & \\
OP & 0.311 & 0.508 & 0.386 & 0.657 & 0.725 & 0.580 & 0.693 & $\mathbf{0 . 8 4 1}$ \\
\hline
\end{tabular}

the inner model path coefficients were calculated. Here, we computed the path coefficients amongst the constructs so as to assess the structural model. The inner model path coefficients as well as the outer loadings which were obtained using the bootstrap method (Davison and Hinkley, 1997) have been summarized in Table 4. The results indicate that all path coefficients were significant as the $t$ statistics obtained from the bootstrap method were all above a value of 2 . The obtained results support hypotheses H1 to H5.

\subsection{Cluster analysis}

To examine hypothesis H6, cluster analysis was first used to group firms in terms of their green HR management practices and training. Thereafter, we performed the multi-group analysis to examine for significance, if any, in the path coefficients amongst the groups. The $K$-means clustering technique was performed wherein the number of clusters was specified, and the cluster seeds were randomly selected. Using similarity principles, we assigned observations to one cluster. Thereafter, the number of clusters to be tested was varied (for example, two, three, \& four) to determine the best number of clusters to be used. The results clustered the companies into two groups, the first contained 92 companies labeled "Low green HR training" and the second comprising the remaining 153 companies labeled "High green HR training."

The next step was to calculate the inner model path coefficients results for each group and compare the results. We found significant differences among two direct path coefficients (green innovation to environmental performance, and to organizational performance), see Table 5. However, there were no significant differences, if any, in the indirect path coefficients. The analysis was repeated for green HR management practices. Two clusters again were identified grouping 167 companies in a cluster representing companies with high green HR management practices and 78 representing those with low green HR management practices. Multi-group analysis detected no significant differences in the path coefficients.

\section{Discussion and conclusion}

Our study was designed to investigate how sustainable capabilities are driven by corporate commitment and through

Table 4

Inner model path coefficients.

\begin{tabular}{|c|c|c|c|c|}
\hline Direct Effect & Original Sample & Sample Mean & Standard Deviation & T Statistics \\
\hline BDACP - > BDRTN & 0.639 & 0.642 & 0.037 & 17.360 \\
\hline BDASM - > EP & 0.289 & 0.289 & 0.065 & 4.419 \\
\hline BDASM - > GRNINV & 0.358 & 0.358 & 0.051 & 7.076 \\
\hline BDASM - > OP & 0.253 & 0.252 & 0.076 & 3.332 \\
\hline BDRTN - > BDASM & 0.515 & 0.516 & 0.055 & 9.409 \\
\hline CCMT - > BDACP & 0.288 & 0.290 & 0.060 & 4.822 \\
\hline CCMT - > GSCC & 0.685 & 0.687 & 0.041 & 16.838 \\
\hline GRNINV - > EP & 0.447 & 0.451 & 0.063 & 7.152 \\
\hline GRNINV - > OP & 0.430 & 0.432 & 0.067 & 6.393 \\
\hline GSCC - > GRNINV & 0.432 & 0.434 & 0.048 & 9.031 \\
\hline \multicolumn{5}{|l|}{ Direct Effect } \\
\hline BDASM -> EP & 0.160 & 0.162 & 0.033 & 4.808 \\
\hline BDASM - > OP & 0.154 & 0.155 & 0.032 & 4.800 \\
\hline BDRTN - > EP & 0.232 & 0.233 & 0.037 & 6.203 \\
\hline BDRTN - > GRNINV & 0.185 & 0.184 & 0.030 & 6.061 \\
\hline BDRTN - > OP & 0.210 & 0.210 & 0.043 & 4.928 \\
\hline CCMT - > BDASM & 0.095 & 0.097 & 0.028 & 3.382 \\
\hline CCMT - > EP & 0.175 & 0.179 & 0.030 & 5.880 \\
\hline CCMT - > GRNINV & 0.330 & 0.333 & 0.040 & 8.241 \\
\hline CCMT - > OP & 0.166 & 0.170 & 0.030 & 5.441 \\
\hline GSCC - > EP & 0.193 & 0.196 & 0.038 & 5.103 \\
\hline GSCC $->$ OP & 0.186 & 0.189 & 0.041 & 4.565 \\
\hline
\end{tabular}


Table 5

Multi-group analysis results.

\begin{tabular}{|c|c|c|c|c|c|c|c|}
\hline & $\begin{array}{l}\text { Path Coeff. } \\
\text { (High HRT) }\end{array}$ & $\begin{array}{l}\text { Path Coeff. } \\
\text { (Low HRT) }\end{array}$ & $\begin{array}{l}\text { t-Values } \\
\text { (High HRT) }\end{array}$ & $\begin{array}{l}\text { t-Values } \\
\text { (Low HRT) }\end{array}$ & $\begin{array}{l}\text { p-Values } \\
\text { (High HRT) }\end{array}$ & $\begin{array}{l}\text { p-Values } \\
\text { (Low HRT) }\end{array}$ & $\begin{array}{l}\text { p-Value } \\
\text { (High vs Low) }\end{array}$ \\
\hline BDACP - > BDRTN & 0.579 & 0.691 & 11.707 & 12.562 & 0.000 & 0.000 & 0.935 \\
\hline BDASM - > EP & 0.194 & 0.423 & 2.222 & 4.104 & 0.026 & 0.000 & 0.954 \\
\hline BDASM - > GRNINV & 0.298 & 0.420 & 4.511 & 5.085 & 0.000 & 0.000 & 0.875 \\
\hline BDASM - > OP & 0.146 & 0.341 & 1.540 & 2.855 & 0.124 & 0.004 & 0.899 \\
\hline BDRTN - > BDASM & 0.479 & 0.503 & 5.678 & 6.409 & 0.000 & 0.000 & 0.575 \\
\hline CCMT $->$ BDACP & 0.185 & 0.328 & 2.137 & 3.600 & 0.033 & 0.000 & 0.871 \\
\hline CCMT - > GSCC & 0.656 & 0.633 & 14.302 & 8.547 & 0.000 & 0.000 & 0.405 \\
\hline GRNINV - > EP & 0.545 & 0.240 & 6.785 & 2.182 & 0.000 & 0.029 & 0.012 \\
\hline GRNINV - > OP & 0.522 & 0.273 & 6.568 & 2.206 & 0.000 & 0.028 & 0.043 \\
\hline GSCC - > GRNINV & 0.530 & 0.328 & 8.879 & 3.532 & 0.000 & 0.000 & 0.029 \\
\hline
\end{tabular}

integration of big data technologies, green HRM practices, and green SCM influences on firms' economic and environmental performance. The study also investigated how green HRM practices impact integration of big data technologies with organizational processes to enhance the relationships between internal and external green SCM practices, and, in turn, their influence on firms' sustainable performance. We obtained and presented the results of our study in the previous section. The results have implications for theory and practice, and are discussed in this section.

\subsection{Implications for theory}

The findings of our study have three implications for advancing theory in the field of big data analytics and firm's sustainable capability.

First, we found that corporate commitment influences big data assimilation through acceptance and routinization routes, which, in turn, enhances firms' sustainable performance. Furthermore, the findings of our study illustrate that corporate commitment also influences the internal and external green SCM practices and they, in turn, impact firms' economic and environmental performance. These findings are consistent with previous studies (e.g., Gunasekaran et al., 2017; Dubey et al., 2017; Roßmann, 2017; Papadopoulos et al., 2017a,b; Cajaiba-Santana, 2014) and our study contributes to further theoretical advancement of how big data technologies help firms to improve upon their financial and environmental performance.

Second, our study found significant differences in the influence of green innovation on firms' financial and environmental performance between high and low green HR training for employees. We found that the linkage of green innovation practices with the economic and environmental performance was stronger for firms where employees received high levels of advanced green HR training. The reason could be that firms derive benefit from green innovation practices, especially when they also invest in enhancing employees' skills, knowledge and competencies through advanced level green HR training. These findings are supported by previous studies (e.g., El-Kassar and Singh, 2018; Gunasekaran et al., 2017; Jabbour and de Sousa Jabbour, 2016). Therefore, our study contributes to the advancement of knowledge on the role of green HR training to enhance the influence of green innovation on firms' financial and environmental performance.

Third, we found that internal and external green SCM practices positively influence firms' financial and environmental performance. The reasons could be that designing and implementing green SCM practices in their business operations helps firms to reduce the environmental impact of their operations, which in turn helps increase their financial performance. This finding of our study finds support in previous studies (e.g., Longoni and Cagliano, 2018; de Sousa Jabbour et al., 2017; Vanalle et al., 2017). Thus, our study contributes to advancing knowledge on why and how green SCM practices can be leveraged to augment economic and environmental performance of the firms.

\subsection{Implications for practice}

Our study offers insights into interventions that firms pursue in using big data technologies, green SCM practices, green HRM practices and corporate commitment for green innovation and sustainable performance. As a result, our study has three main practical implications for leaders and managers to practice to enhance their firms' sustainable performance.

First, our study offers the suggestion to firms to adopt a comprehensive and viable process to integrate big data technologies into their strategic and operational architectures for attaining sustainable performance. Firms collect excessive amounts of data across different brackets - internal and the external business practices - and huge information and data become more challenging for decision makers to analyze and leverage their potential and hidden values. Next comes the relevance of utilizing big data technologies that offer huge opportunities pertinent to businesses, especially those operating in different fields and industrial sectors, and that in turn increases their productivity and both their environmental and financial performance.

Second, our study suggests that firms should develop the sustainable capabilities needed to achieve sustainable performance through strong corporate commitment to installing and practicing green SCM practices. In other words, firms should have strong commitment to internal green SCM practices and green supply chain partners and help support and monitor successes of such internal and external SCM practices for sustainable performance to stay competitive in dynamic markets. Our study suggests that firms should have formal environmental policy in place and their leaders and managers should support and implement such environmentfriendly practices such as the internal and external green SCM, green technologies, and green innovation to enhance their sustainable capabilities for improved financial and environmental performance.

Third, based on the findings of our study, we suggest that technological challenges in assimilating big data become huge when firms consciously embrace internal and external green SCM and sustainable practices. The business opportunities and challenges could be handled effectively when firms possess corporate commitment and green HR practices and ask employees to undergo advanced training on green HRM practices, which, in turn, enhances firms' financial and environmental performance. Green HR practices facilitate adoption of green management, green technologies, and green operations management essential for organizational sustainability and improved firm's performance. 


\subsection{Limitations and suggestions for future research}

As with any study, this study is not without limitations. In this section, we mention limitations along with suggestions for future research. First, our study is based on single source data. We suggest that future studies using our research framework should go multisource and/or multi-time dataset. Second, our study relies on quantitate data to examine the linkages amongst corporate commitment, big data technologies, green SCM practices, green HRM practices, green innovation and sustainable capabilities. Future study can extend our research framework and use mixed methods to take care of this limitation of our study. Third, we conducted our study in two GCC countries - the UAE and the KSA and two countries from the MENA region - Egypt and Lebanon. Future research should sample other GCC and MENA countries along with the UAE, the KSA, Egypt and Lebanon for better generalization for the study in the Arab world, which comprises countries from the GCC and the MENA regions. Having said that, the findings of our study have strong theoretical and practical implications mentioned above.

\section{Appendix A. Supplementary data}

Supplementary data to this article can be found online at https://doi.org/10.1016/j.jclepro.2018.12.199.

\section{References}

Acharya, A., Singh, S.K., Pereira, V., Singh, P., 2018. Big data, knowledge co-creation, and decision making in fashion industry. Int. J. Inf. Manag. 42, 90-101.

Akter, S., Wamba, S.F., Gunasekaran, A., Dubey, R., Childe, S.J., 2016. How to improve firm performance using big data analytics capability and business strategy alignment? Int. J. Prod. Econ. 182, 113-131.

Amui, L.B.L., Jabbour, C.J.C., de Sousa Jabbour, A.B.L., Kannan, D., 2017. Sustainability as a dynamic organizational capability: a systematic review and a future agenda toward a sustainable transition. J. Clean. Prod. 142, 308-322.

An, Q., Wen, Y., Xiong, B., Yang, M., Chen, X., 2017. Allocation of carbon dioxide emission permits with the minimum cost for Chinese provinces in big data environment. J. Clean. Prod. 142, 886-893.

Argote, L., 2012. Organizational Learning: Creating, Retaining and Transferring Knowledge. Springer Science \& Business Media.

Astrachan, J.H., Kolenko, T.A., 1994. A neglected factor explaining family business success: human resource practices. Fam. Bus. Rev. 7 (3), 251-262.

Bansal, P., DesJardine, M.R., 2014. Business sustainability: it is about time. Strat. Organ. 12 (1), 70-78.

Boudreau, J., Hopp, W., McClain, J.O., Thomas, L.J., 2003. On the interface between operations and human resources management. Manuf. Serv. Oper. Manag. 5 (3), $179-202$.

Braganza, A., Brooks, L., Nepelski, D., Ali, M., Moro, R., 2017. Resource management in big data initiatives: processes and dynamic capabilities. J. Bus. Res. 70, 328-337.

Cajaiba-Santana, G., 2014. Social innovation: moving the field forward. a conceptual framework. Technol. Forecast. Soc. Change 82, 42-51.

Carvalho, H., Govindan, K., Azevedo, S.G., Cruz-Machado, V., 2017. Modelling green and lean supply chains: an eco-efficiency perspective. Resour. Conserv. Recycl. 120, 75-87.

Chang, C.H., 2011. The influence of corporate environmental ethics on competitive advantage: the mediation role of green innovation. J. Bus. Ethics 104 (3), $361-370$.

Chen, C.M., Delmas, M.A., 2012. Measuring eco-inefficiency: a new frontier approach. Oper. Res. 60 (5), 1064-1079.

Chen, C.P., Zhang, C.Y., 2014. Data-intensive applications, challenges, techniques and technologies: a survey on Big Data. Inf. Sci. 275, 314-347.

Chen, D.Q., Preston, D.S., Swink, M., 2015. How the use of big data analytics affects value creation in supply chain management. J. Manag. Inf. Syst. 32 (4), 4-39.

Chen, Y.S., Chang, C.H., 2012. Enhance green purchase intentions: the roles of green perceived value, green perceived risk, and green trust. Manag. Decis. 50 (3), 502-520.

Chen, Y.S., Lai, S.B., Wen, C.T., 2006. The influence of green innovation performance on corporate advantage in Taiwan. J. Bus. Ethics 67 (4), 331-339.

Chin, W., 1998. Issues and opinion on structural equation modeling. MIS Q. 22, $7-16$

Chiou, T.Y., Chan, H.K., Lettice, F., Chung, S.H., 2011. The influence of greening the suppliers and green innovation on environmental performance and competitive advantage in Taiwan. Transport. Res. E Logist. Transport. Rev. 47 (6), 822-836.

Chithambaranathan, P., Subramanian, N., Gunasekaran, A., Palaniappan, P.K., 2015.
Service supply chain environmental performance evaluation using grey based hybrid MCDM approach. Int. J. Prod. Econ. 166, 163-176.

Dai, J., Cantor, D.E., Montabon, F.L., 2017. Examining corporate environmental proactivity and operational performance: a strategy-structure-capabilitiesperformance perspective within a green context. Int. J. Prod. Econ. 193, $272-280$.

Dao, V., Langella, I., Carbo, J., 2011. From green to sustainability: information Technology and an integrated sustainability framework. J. Strat. Inf. Syst. 20 (1) 63-79.

Davison, A.C., Hinkley, D.V., 1997. Bootstrap Methods and Their Application. Cambridge University Press, Cambridge.

de Camargo Fiorini, P., Seles, B.M.R.P., Jabbour, C.J.C., Mariano, E.B., de Sousa Jabbour, A.B.L., 2018. Management theory and big data literature: from a review to a research agenda. Int. J. Inf. Manag. 43, 112-129.

De Kok, J.M., Uhlaner, L.M., Thurik, A.R., 2006. Professional HRM practices in family owned-managed enterprises. J. Small Bus. Manag. 44 (3), 441-460.

De Sarbo, W.S., Wedel, M., Vriens, M., Ramaswamy, V., 1992. Latent class metric conjoint analysis. Market. Lett. 3 (3), 273-288.

de Sousa Jabbour, A.B.L., Vazquez-Brust, D., Jabbour, C.J.C., Latan, H., 2017. Green supply chain practices and environmental performance in Brazil: survey, case studies, and implications for B2B. Ind. Market. Manag. 66, 13-28.

Dubey, R., Gunasekaran, A., Childe, S.J., Papadopoulos, T., Luo, Z., Wamba, S.F. Roubaud, D., 2017. Can big data and predictive analytics improve social and environmental sustainability? Technol. Forecast. Soc. Change (Online). https:// doi.org/10.1016/j.techfore.2017.06.020.

Eisenhardt, K.M., Martin, J.A., 2000. Dynamic capabilities: what are they? Strat Manag. J. 21 (10-11), 1105-1121.

El-Kassar, A., Singh, S.K., 2018. Green innovation and organizational performance: the influence of big data and the moderating role of management commitment and HR practices. Technol. Forecast. Soc. Change (Online). https://doi.org/10. 1016/j.techfore.2017.12.016.

Fornell, C.G., Larcker, D.F., 1981. Evaluating structural equation models with unobservable variables and measurement error. J. Market. Res. 18 (1), 39-50.

Fosso Wamba, S., Akter, S., Coltman, T., Ngai, W.T.E., 2015. Guest editorial: information technology-enabled supply chain management. Prod. Plann. Contr. 26 (12), 933-944.

Fosso-Wamba, S., Gunasekaran, A., Akter, S., Ren, S.J.F., Dubey, R., Childe, S.J., 2017. Big data analytics and firm performance: effects of dynamic capabilities. J. Bus. Res. 70, 356-365.

Gast, J., Gundolf, K., Cesinger, B., 2017. Doing business in a green way: a systematic review of the ecological sustainability entrepreneurship literature and future research directions. J. Clean. Prod. 147, 44-56.

Gholami, R., Sulaiman, A.B., Ramayah, T., Molla, A., 2013. Senior managers perception on green information systems (IS) adoption and environmental performance: results from a field survey. Inf. Manag. 50 (7), 431-438.

Gmelin, H., Seuring, S., 2014. Achieving sustainable new product development by integrating product life-cycle management capabilities. Int. J. Prod. Econ. 154, 166-177.

Govindan, K., Muduli, K., Devika, K., Barve, A., 2016. Investigation of the influential strength of factors on adoption of green supply chain management practices: an Indian mining scenario. Resour. Conserv. Recycl. 107, 185-194.

Govindan, K., Sarkis, J., Jabbour, C.J.C., Zhu, Q., Geng, Y., 2014. Eco-efficiency based green supply chain management: current status and opportunities. Eur. J Operat. Res. 233 (2), 293-298.

Govindan, K., Soleimani, H., Kannan, D., 2015. Reverse logistics and closed-loop supply chain: a comprehensive review to explore the future. Eur. J. Oper. Res. 240 (3), 603-626.

Gunasekaran, A., Papadopoulos, T., Dubey, R., Wamba, S.F., Childe, S.J., Hazen, B. Akter, S., 2017. Big data and predictive analytics for supply chain and organizational performance. J. Bus. Res. 70, 308-317.

Hampton, S.E., Strasser, C.A., Tewksbury, J.J., Gram, W.K., Budden, A.E., Batcheller, A.L., Porter, J.H., 2013. Big data and the future of ecology. Front. Ecol. Environ. 11 (3), 156-162.

Hashem, I.A.T., Yaqoob, I., Anuar, N.B., Mokhtar, S., Gani, A., Khan, S.U., 2015. The rise of "big data" on cloud computing: review and open research issues. Inf. Syst. 47 , 98-115.

Hazen, B.T., Overstreet, R.E., Cegielski, C.G., 2012. Supply chain innovation diffusion: going beyond adoption. Int. J. Logist. Manag. 23 (1), 119-134.

Hulland, J., 1999. Use of partial least squares (PLS) in strategic management research: a review of four recent studies. Strat. Manag. J. 20 (2), 195-204.

Jabbour, C.J.C., Almada Santos, F.C., Fonseca, S.A., Nagano, M.S., 2013. Green teams: understanding their roles in the environmental management of companies located in Brazil. J. Clean. Prod. 46, 58-66.

Jabbour, C.J.C., de Sousa Jabbour, A.B.L., 2016. Green human resource management and green supply chain management: linking two emerging agendas. J. Clean Prod. 112 (3), 1824-1833.

Jabbour, C.J.C., Santos, F.C.A., 2008. Relationships between human resource dimensions and environmental management in companies: proposal of a model J. Clean. Prod. 16 (1), 51-58.

Jackson, S., Renwick, D., Jabbour, C.J.C., Muller-Camen, M., 2011. State-of-the-Art and future directions for green human resource management. German J. Res. Human Resour. Manag. 25 (2), 99-116.

Jackson, S.E., Seo, J., 2010. The greening of strategic HRM scholarship. Organ. Manag. J. 7 (4), 278-290.

Jeble, S., Dubey, R., Childe, S.J., Papadopoulos, T., Roubaud, D., Prakash, A., 2018 
Impact of big data and predictive analytics capability on supply chain sustainability. Int. J. Logist. Manag. 29 (2), 513-538.

Kamakura, W.A., Wedel, M., 2000. Factor analysis and missing data. J. Market. Res. 37 (4), 490-498.

Kindström, D., Kowalkowski, C., Sandberg, E., 2013. Enabling service innovation: a dynamic capabilities approach. J. Bus. Res. 66 (8), 1063-1073.

Kline, R., 2012. Beyond Significance Testing. American Psychological Association, Washington, DC.

Liang, H., Saraf, N., Hu, Q. Xue, Y., 2007. Assimilation of enterprise systems: the effect of institutional pressures and the mediating role of top management. MIS Q. 31 (1), 59-87.

Lin, R.J., Tan, K.H., Geng, Y., 2013. Market demand, green product innovation, and firm performance: evidence from Vietnam motorcycle industry. J. Clean. Prod. 40, 101-107.

Longoni, A., Cagliano, R., 2018. Inclusive environmental disclosure practices and firm performance: the role of green supply chain management. Int. J. Oper Prod. Manag. 38 (9), 1815-1835.

Mishra, D., Gunasekaran, A., Papadopoulos, T., Childe, S.J., 2018. Big Data and supply chain management: a review and bibliometric analysis. Ann. Oper. Res. 270 (1-2), 313-336.

Nguyen, T., Li, Z.H.O.U., Spiegler, V., Ieromonachou, P., Lin, Y., 2017. Big data analytics in supply chain management: a state-of-the-art literature review. Comput. Oper. Res. 98, 254-264.

Nunnally, J.C., Bernstein, I.H., 1994. Psychological Theory. McGraw-Hill, New York NY.

Papadopoulos, T., Gunasekaran, A., Dubey, R., Altay, N., Childe, S.J., Fosso-Wamba, S. 2017a. The role of big data in explaining disaster resilience in supply chains for sustainability. J. Clean. Prod. 142, 1108-1118.

Papadopoulos, T., Gunasekaran, A., Dubey, R., Fosso Wamba, S., 2017b. Big data and analytics in operations and supply chain management: managerial aspects and practical challenges. Prod. Plann. Contr. 28 (11-12), 873-876.

Rajesh, R., 2017. Technological capabilities and supply chain resilience of firms: relational analysis using Total Interpretive Structural Modeling (TISM). Technol. Forecast. Soc. Change 118, 161-169.

Roßmann, B., Canzaniello, A., von der Gracht, H., Hartmann, E., 2018. The future and social impact of big data analytics in supply chain management: results from a delphi study. Technol. Forecast. Soc. Change 130, 135-149.

Roxas, B., Lindsay, V., 2012. Social desirability bias in survey research on sustainable development in small firms: an exploratory analysis of survey mode effect. Bus. Strateg. Environ. 21 (4), 223-235.

Sanders, N.R., 2014. Big Data Driven Supply Chain Management: A Framework for Implementing Analytics and Turning Information into Intelligence. Pearson Education, Upper Saddle River.

Seles, B.M.R.P., de Sousa Jabbour, A.B.L., Jabbour, C.J.C., de Camargo Fiorini, P., Mohd Yusoff, Y. Thomé, A.M.T., 2018. Business opportunities and challenges as the two sides of the climate change: corporate responses and potential implications for big data management towards a low carbon society. J. Clean. Prod. 189, $763-774$

Song, M., Cen, L., Zheng, Z., Fisher, R., Liang, X., Wang, Y., Huisingh, D., 2017. How would big data support societal development and environmental sustainability? Insights and practices. J. Clean. Prod. 142, 489-500.

Tan, K.H., Zhan, Y., Ji, G., Ye, F., Chang, C., 2015. Harvesting big data to enhance supply chain innovation capabilities: an analytic infrastructure based on deduction graph. Int. J. Prod. Econ. 165, 223-233.

Teece, D.J., Pisano, G., Shuen, A., 1997. Dynamic capabilities and strategic management. Strat. Manag. J. 18 (7), 509-533.

Tien, J.M., 2013. Big data: unleashing information. J. Syst. Sci. Syst. Eng. 22 (2), 127-151.

Vanalle, R.M., Ganga, G.M.D., Godinho Filho, M., Lucato, W.C., 2017. Green supply chain management: an investigation of pressures, practices, and performance within the Brazilian automotive supply chain. J. Clean. Prod. 151, 250-259.

Waller, M.A., Fawcett, S.E., 2013. Data science, predictive analytics, and big data: a revolution that will transform supply chain design and management. J. Bus. Logist. 34 (2), 77-84.

Wang, S.H., Song, M.L., 2014. Review of hidden carbon emissions, trade, and labor income share in China, 2001-2011. Energy Pol. 74, 395-405.

Wang, Y., Kung, L., Byrd, T.A., 2018. Big data analytics: understanding its capabilities and potential benefits for healthcare organizations. Technol. Forecast. Soc Change 126, 3-13.

Weng, H.H.R., Chen, J.S., Chen, P.C., 2015. Effects of green innovation on environmental and corporate performance: a stakeholder perspective. Sustainability 7 (5), 4997-5026.

Wetzels, M., Odekerken-Schröder, G., Van Oppen, C., 2009. Using PLS path modeling for assessing hierarchical construct models: guidelines and empirical illustration. MIS Q. 33 (1), 177-195.

Yen, Y.X., Yen, S.Y., 2012. Top-management's role in adopting green purchasing standards in high-tech industrial firms. J. Bus. Res. 65 (7), 951-959.

Zhao, R., Liu, Y., Zhang, N., Huang, T., 2017. An optimization model for green supply chain management by using a big data analytic approach. J. Clean. Prod. 142, 1085-1097.

Zmud, R.W., Apple, L.E., 1992. Measuring technology incorporation/infusion. J. Prod. Innovat. Manag. 9 (2), 148-155.

Zollo, M., Winter, S.G., 2002. Deliberate learning and the evolution of dynamic capabilities. Organ. Sci. 13 (3), 339-351.

Sanjay Kumar Singh, Ph.D. is Associate Professor of Management, College of Business, Abu Dhabi University, Abu Dhabi, UAE. His research areas include Big data analytics, Knowledge management, Organizational learning, Leadership \& Culture and International HRM. He can be reached at sanjay.singh@adu.ac.ae

Abdul-Nasser El-Kassar, $P h D$ is Associate Professor of Quantitative Methods, Adnan Kassar School of Business, Lebanese American University, Beirut, Lebanon. His research areas include Cryptography, Abstract algebra, Number theory, and Big data analytics. He can be reached at abdulnasser.kassar@lau.edu.lb 